des Longitudes. He was twice married, his second wife, whom he married in 1792, being the daughter of the astronomer Lemonnier. To this union Lagrange owed much of the happiness of his later years. At the age of seventy-seven years, in the spring of 1813 , he was attacked by fainting fits. On April 8 he had a last conversation with Lacépède, Monge and Chaptal, and two days later he passed away. At his funeral in the Panthéon, orations were delivered by Lacépède, then Chancellor of the Legion of Honour, and Laplace. His life was written by Delambre. In 1877 his statue was placed in the hall of the Bureau des Longitudes, and between 1866 and 1892 his works, edited by Serret and Darboux, were published in fourteen volumes.

\section{Prof. Wilhelm Schmidt}

Ar the annual meeting of the Royal Meteorological Society on January 15, the Symons Gold Medal was presented to Prof. Wilhelm Schmidt, director of the Zentralanstalt für Meteorologie und Geodynamik at Vienna. In presenting the Medal, the president, Lieut.-Col. E. Gold, said that Prof. Schmidt has written important papers in many branches of meteorology. In 1925 he published his book "Der Massenaustausch in freier Luft und verwandte Erscheinungen" which dealt comprehensively with the mechanics of the exchange of air, especially the part played by turbulence, and did much to open up a new chapter in meteorology. In recent years he has devoted great attention to the new subject of 'microclimatology', which deals with the finer details of climatology, and is especially important for agriculture. In 1934 he lectured on this subject before the Royal Meteorological Society, choosing as his title "Observations on Local Climatology in Austrian Mountains". $\mathrm{He}$ has also carried out detailed investigations on the distribution of tem. perature in Alpine lakes. In 1935 Prof. Schmidt succeeded the late Prof. A. Wallen as president of the International Commission for Agricultural Meteorology, a subject which he has done much to foster. Prof. Schmidt was unable to be present to receive the Medal in person, and Herr von Blass, of the Austrian Embassy, attended on his behalf.

\section{U.S. Stratosphere Balloon Explorer II}

THE National Geographic Magazine of January contains a graphic account together with many interesting photographs of the stratosphere flight of November 11, 1935, of Explorer II piloted by Capts. A. W. Stevens and O. A. Anderson. The height achieved was $72,395 \mathrm{ft}$., corresponding to a pressure of $29.5 \mathrm{~mm}$. The duration of the flight was $8 \mathrm{hr}$. 13 min., commencing at 7.01 a.m. Mountain Standard Time from Stratobowl near Rapid City in South Dakota and finishing at 3.14 p.m. 12 miles south of White Lake. The flight was completely successful in all its objectives, and we are promised in a future issue of the magazine a detailed account of the scientific results obtained. Capt. Stevens makes mention of practically all the instruments that were referred to in the previous account given of the balloon in Nature of June 22, 1935 ; but omits any reference to the Wilson expansion chamber. We hope that this omission is purely accidental, because it is felt that so much could be learned of cosmic rays from observation of tracks made at these high altitudes.

Remarkably little went wrong with the arrangements; the fliers had the same experience as M. Max Cosyns. They were discomfited by the fact that the balloon refused to turn, which resulted in uncomfortable temperature conditions within the gondola. We are told that the thermometer placed within the envelope and viewed by binoculars during the flight of the balloon functioned properly, and proved most valuable in enabling the travellers to estimate exactly how much ballast to retain in order to prevent too precipitate a descent. The higher the internal temperature of the gas-helium in this case - the more is spilled at the top of the flight and the less will be the buoyancy during the descent. Stevens says that for him the most exciting moment during the flight was when at a height of $65,000 \mathrm{ft}$. the balloon became fully spherical and the central appendix opened giving a full view within the mighty sphere above them. One other point interesting to readers of NATURE is an account of the reality of the inversion of the temperature gradient. Actual data for the external temperature are not yet available, but the interior of the gondola rose from $21^{\circ} \mathrm{F}$. at a medium height to $43^{\circ} \mathrm{F}$. at the top of the flight. Very diverse air currents were met. At the start, the travel was to the south-east, in rising near the top a little north of east and on the descent first due south and then due north. Doubtless many volumes will be filled when all the data available have been worked up. A remarkable feature of the event was the diversity and number of individuals and of public bodies mentioned by Capt. Stevens as having taken an active part in this great experiment. The whole was a triumph of co-operation.

\section{Mr. Ellsworth's Antarctic Flight}

IT was on November 23 last year that Mr. Lincoln Ellsworth and his pilot, Mr. H. H. Kenyon, left Dundee Island off Graham Land in their attempt to reach the Bay of Whales in the Ross Sea in a transantarctic flight of more than two thousand miles. Their last radio message was received eight hours after their departure. In the hope that the fliers had succeeded in reaching their destination, the R.R.S. Discovery $I I$ was diverted from her work to make her way to the Bay of Whales, where she arrived on January 16 and found the two airmen alive and well at the camp known as Little America, where Admiral Byrd had left petrol, stores and huts two years ago. Mr. Ellsworth's own ship Wyatt Earp was also making for the Bay of Whales after visiting Charcot Land and other places according to prearranged orders. It appears that the American aeroplane descended twenty miles short of Little America owing to lack of fuel. The men sledged to safety, for the plane carried a small sledge. Their wireless set failed, and 
hence the many weeks of anxiety as to their fate. Details of the flight are awaited with interest, since the route was across the unexplored Hearst Land and presumably over the unknown extension of the Queen Maud Ranges.

\section{Jubilee of the Aga Khan}

IN the celebration of the jubilee of the Aga Khan on January 19 and four succeeding days in Bombay, one of the most striking incidents, perhaps for its incongruity, has been the assessment of the tribute from his followers to mark the occasion by the ceremonial of weighing His Highness against bars of gold in a huge balance. This is the usual method by which the contributions to his personal expenditure are determined annually; but, on this occasion, the $£ 25,125$ representing the value of the weight of gold at which he 'tipped the balance' is to be devoted by his decision to the benefit of his community. By his activities in Europe the Aga Khan has become so intimately known to the public that the significance of his position in India is sometimes overlooked. Without territory, as hereditary Imam of the Ismailia sect, he is spiritual head and virtual dictator to a body variously estimated at from four to twenty millions, and distributed over north and east Africa, Central Asia, India and Burma. Although the Ismailia sect is regarded as heretical by both Sunni and Shiah, from the latter of whom it originally derived, in India the Aga Khan by his personal qualities, his influence and his services, has come to be regarded as in some sort the representative of the Moslem community. His hereditary position and influence are derived not so much from his descent from the Prophet, as from the fact that he is of the line of the "Old Man of the Mountains", the legendary figure of the Middle Ages, by whom the Ismailia sect was founded, and whose fanatical followers, the Assassins, were said to be devoted to his service through the use of hashish, whence their name. The leaders of the Ismailia dominated Syria in the twelfth century until overcome by the Mongols. They then settled in Persia, the grandfather of the Aga Khan going to Bombay in 1845 .

\section{Cave Exploration in South Australia}

A Remarkable series of discoveries made in the course of cave exploration in South Australia is described by the Adelaide correspondent of The Times in the issue of January 16. The caves are situated in the Nullarbour Plain, which itself is not the least remarkable feature in the geography of South Australia. It is a treeless expanse of some 38,000 square miles in extent, which has made a deep impression even on the imagination of the aborigines; for it figures prominently in their legendary lore, one belief being that it is the home of an immense serpent, which devours human beings who enter its province. At different times a number of attempts have been made to explore the caves of the Plain, but without marked success. The present expedition was carried out by a party of nine, of whom the leader was Capt. Maitland Thompson of
Port Lincoln. It started from Ceduna in November last. A number of caves were examined, of which the most impressive was the Koonalda Cave, situated sixty miles from Eucla. The entrance was in an almost vertical shaft and was reached by ladder. Passing through a chamber eight hundred feet in circumference, the exploring party penetrated for more than half a mile to a narrow passage leading to a subterranean well fifty feet in diameter; while another tunnel was followed to a distance of $2,400 \mathrm{ft}$. from the entrance until the passage forked and further progress was blocked by water. An interesting piece of evidence of previous penetration was found near the well in the form of an impression in the sand of the foot of an aboriginal.

IN the Weebubble Cave, a canoe, which the party had brought with them, came into use and after effecting an entry to a circular entrance hole three hundred feet across in the face of an eighty foot cliff, a tunnel was followed until a vast room, of which the back wall was four hundred yards from the entrance, was reached. Here the water, $320 \mathrm{ft}$. below the surface, was at the level of the sea fourteen miles away. The lake was found to have a depth of twenty feet at the edge and more than two hundred feet at the centre. An interesting piece of evidence of the attitude of the aborigines towards these remarkable caves was found at the Murrawidginnie Cave, where at the entrance were a number of imprints of the human hand (usually the left) in red on the surface of the rock, which was also daubed or stained with red ochre. The practice of the Australian aboriginal of leaving the imprint of his hand on a rock surface has been recorded from numerous districts on the continent and is a custom which he shares with the Bushman and palæolithic man of Europe. Frequently the fingers show mutilations. Various explanations of the custom have been offered, and it may be that in the present instance it is correctly interpreted as a taboo sign, especially as it is believed that the cave may have been used as a store-house for the churingas and other emblems which were used in tribal ceremonial. Among other caves explored was the Abrakurrie Cave, where a drop of $250 \mathrm{ft}$. led to a cavern 1,200 ft. long, $160 \mathrm{ft}$. wide and $150 \mathrm{ft}$. high. It is proposed to follow this very successful exploration with further investigations, the next immediate objective being a search for the eaverns known as "The Catacombs", of which the situation, frequently sought, appears to have been established by a recent aerial reconnaissance.

\section{Association of British Zbologists}

THE annual meeting of the Association of British Zoologists was held in the rooms of the Zoological Society on Saturday, January 4, Prof. J. S. Huxley being in the chair. At the previous meeting the Association had appointed a committee to inquire into any means which could be devised to lessen the confusion at present caused by frequent changes in the scientific names of animals, and especially of the common species used in schools and universities as 